\title{
Cancer Epidemiology Based on Hospital-Based Cancer Registry at National Referral Hospital of Indonesia, 2013
}

\author{
S. Gondhowiardjo, ${ }^{1, *}$ K.E. Brohet, ${ }^{1}$ C.A. Nugroho, ${ }^{1}$ S.S. Panigoro, ${ }^{2}$ M. Adham, ${ }^{3}$ \\ G.B. Prajogi, ${ }^{1}$ A. Giselvania, ${ }^{1}$ A.R.A.H. Hamid, ${ }^{4}$ E. Widyastuti, ${ }^{5}$ Y. Prabowo, ${ }^{6}$ T. Aninditha, ${ }^{7}$ G. \\ Purwoto, ${ }^{8}$ R.A. Aman, ${ }^{9}$ T.P. Siregar, ${ }^{10}$ A.D. Siswoyo, ${ }^{10}$ Lisnawati, ${ }^{11}$ D.R. Handjari, ${ }^{11}$ \\ T.D. Atmakusuma, ${ }^{12}$ W. Rajabto, ${ }^{12}$ N.A. Mulansari, ${ }^{12}$ N. Ratna, ${ }^{13}$ C.W. Pitoyo, ${ }^{12}$ D. Kartini, ${ }^{2}$ E.D.Yulian, ${ }^{2}$ \\ R.S. Andrisa, ${ }^{14}$ W.S. Jeo, ${ }^{2}$ R.K. Wardhani, ${ }^{15}$ T.F.U. Tambunan, ${ }^{15}$ \\ F.Agiananda, ${ }^{16}$ Priyambodho, ${ }^{17}$ D.Safitri, ${ }^{1}$ F.W. Anggraini, ${ }^{1}$ I. Nashiroh, ${ }^{1}$ L. Fitrianti ${ }^{1}$
}

\begin{abstract}
${ }^{1}$ Department of Radiation Oncology, ${ }^{2}$ Department of Surgery, ${ }^{3}$ Department of Otorhinolaryngology, ${ }^{4}$ Department of Urology, ${ }^{5}$ Department of Pediatric, ${ }^{6}$ Department of Orthopedics, ${ }^{7}$ Department of Neurology, ${ }^{8}$ Department of Obstetrics and Gynecology, ${ }^{9}$ Department of Neurosurgery, ${ }^{10}$ Department of Radiology, ${ }^{11}$ Department of Anatomical Pathology,

${ }^{12}$ Department of Internal Medicine, ${ }^{13}$ Department of Nutrition Science Clinic, ${ }^{14}$ Department of Ophthalmology, ${ }^{15}$ Department of Medical Rehabilitation, ${ }^{16}$ Department of Psychiatry, ${ }^{17}$ Department of Anesthesiology and Intensive Therapy Faculty of Medicine Universitas Indonesia-Cipto Mangunkusumo Hospital, Jakarta
\end{abstract}

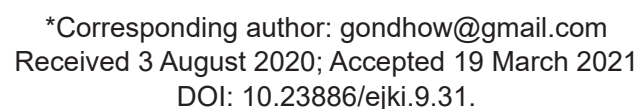

\section{Abstract}

Cancer is the primary cause of death in developed or developing country. To develop hospital policy and research, comprehensive epidemiological data are needed. This research aims to provide epidemiological and demographical profiles of cancer from a hospital-based cancer registry (HBCR) at Cipto Mangunkusumo Hospital in 2013. This is a descriptive study involving cancer patients based on the HBCR from January-December 2013. Cancer frequency at the hospital in 2013 was 4,915 cases, with the majority of the patients were 45-54 years old, regardless of their sexes. Sex ratio was 3:2 for women and men, respectively. The most frequent age of female patients was 45-54 years old, while for male patients was 55-64 years old. In 2013, the hospital served more cancer patients from outside Jakarta than from Jakarta itself. Breast cancer, cervical cancer, and hematopoietic and reticuloendothelial systems cancer were the most prevalent types of cancer in women. Additionally, hematopoietic and reticuloendothelial systems cancer, nasopharyngeal cancer, and lymphoma were the most prevalent types of cancer in men. Most breast and cervical cancers came in either locally advanced or advanced stage. Histopathological examination revealed that most prevalent types of cancer were Infiltrating duct carcinoma of breast, nonkeratinized squamous cell carcinoma of cervix, and acute lymphoblastic leukemia.

Keywords: hospital-based cancer registry, epidemiology, histopathology, staging, demography.

\section{Epidemiologi Kanker Berdasarkan Registrasi Kanker Berbasis Rumah Sakit di Pusat Rujukan Nasional Indonesia, 2013}

\begin{abstract}
Abstrak
Kanker merupakan penyebab kematian utama pada negara maju maupun berkembang. Untuk menentukan arah kebijakan rumah sakit dan penelitian, diperlukan data komprehensif mengenai epidemiologi kanker. Penelitian ini bertujuan untuk memberikan gambaran profil epidemiologi dan demografi kanker di Rumah Sakit Cipto Mangunkusumo berdasarkan Registrasi Kanker Berbasis Rumah Sakit (HBCR) tahun 2013. Studi ini menggunakan desain deskriptif yang melibatkan semua pasien kanker berdasarkan data HBCR. pada Januari-Desember 2013. Frekuensi kanker di RSCM pada tahun 2013 adalah 4,915 kasus, dengan mayoritas pasien berusia 45-54 tahun, baik jenis kelamin wanita ataupun pria. Rasio jenis kelamin perempuan dibandingkan laki-laki adalah 3:2. Rentang usia paling sering pada pasien wanita adalah 45-54 tahun, sedangkan pada laki-laki adalah 55-64 tahun. Pada tahun 2013, RSCM lebih banyak melayani pasien kanker dari luar Jakarta dibandingkan dari Jakarta. Kanker payudara, serviks dan kanker darah dan sistem retikuloendotel merupakan jenis kanker tersering pada perempuan. Sebagai tambahan, kanker darah dan sistem retikuloendotel, nasofaring dan kegasanan kelenjar getah bening (limfoma) merupakan kanker tersering pada laki-laki. Sebagian besar kanker payudara dan serviks datang dengan stadium lokal lanjut atau lanjut. Pemeriksaan histopatologi menunjukkan bahwa tipe patologi kanker tersering adalah karsinoma duktal invasif pada kanker payudara, karsinoma sel skuamosa tidak berkeratin pada kanker serviks, dan leukemia limfoblastik akut.

Kata kunci: Registrasi kanker berbasis rumah sakit, epidemiologi, histopatologi, stadium, demografi.
\end{abstract}




\section{Introduction}

Cancer is in the top three of the most prevalent diseases and it is the leading cause of death in world. Epidemiological pattern is varied among the countries. Although developing country is more populous than the developed one, only $57 \%$ cancer cases and $65 \%$ of the deaths caused by cancer in developing countries. In the future, the burden of cancer will shift to developing countries due to aging populations and exposure of significant cancer risk factors, such as tobacco smoking. ${ }^{1}$

Data from Riskesdas 2013 showed that cancer prevalence is 1.4 per 1000 person. ${ }^{2}$ Data from Badan Penyelenggara Jaminan Sosial/BPJS (Healthcare Social Security Administrative Body) 2015 reported that cancer medication is on the top three cases covered by the insurance with $1,325,776$ cases in total and cost 2294 trillion rupiahs. ${ }^{3}$

Table 1. The Proportion of Cancer Based on Tumor Location in RSCM, 2013

\begin{tabular}{|c|c|c|c|c|c|}
\hline Organs & $\mathbf{n}$ & $\%$ & Organs & $\mathbf{n}$ & $\%$ \\
\hline Accessory sinuses & 36 & 0.73 & Other and unspecified female genital organs & 1 & 0.02 \\
\hline Adrenal gland & 6 & 0.12 & Other endocrine glands and related structures & 31 & 0.63 \\
\hline Anus & 2 & 0.04 & Ovary & 222 & 4.52 \\
\hline Bladder & 69 & 1.40 & Palate & 8 & 0.16 \\
\hline Bones, joints, and articular cartilage & 99 & 2.01 & Pancreas & 53 & 1.08 \\
\hline Brain & 124 & 2.52 & Parotid gland & 24 & 0.49 \\
\hline Breast & 655 & 13.33 & Penis & 8 & 0.16 \\
\hline Bronchus and lung & 112 & 2.28 & Peripheral nerves and autonomic nervous system & 11 & 0.22 \\
\hline Cervix uteri & 617 & 12.55 & Pharynx & 1 & 0.02 \\
\hline Colon & 128 & 2.60 & Placenta & 13 & 0.26 \\
\hline $\begin{array}{l}\text { Connective, subcutaneous and other } \\
\text { soft tissue }\end{array}$ & 102 & 2.08 & Prostate gland & 112 & 2.28 \\
\hline Corpus uteri & 89 & 1.81 & Rectosigmoid junction & 14 & 0.28 \\
\hline Esophagus & 22 & 0.45 & Rectum & 159 & 3.23 \\
\hline Eye and adnexa & 70 & 1.42 & Retroperitoneum and peritoneum & 9 & 0.18 \\
\hline Floor of mouth & 2 & 0.04 & Salivary gland & 13 & 0.26 \\
\hline $\begin{array}{l}\text { Gallbladder, other and unspecified } \\
\text { parts of billiary tract }\end{array}$ & 31 & 0.63 & Scrotum & 1 & 0.02 \\
\hline Gum & 6 & 0.12 & Skin & 155 & 3.15 \\
\hline Heart, mediastinum, and pleura & 18 & 0.37 & Small intestine & 11 & 0.22 \\
\hline $\begin{array}{l}\text { Hematopoietic and reticuloendothelial } \\
\text { systems }\end{array}$ & 441 & 8.97 & $\begin{array}{l}\text { Spinal cord, cranial nerves, and other parts of } \\
\text { central } n \text {. System }\end{array}$ & 14 & 0,28 \\
\hline Hypopharynx & 6 & 0.12 & Stomach & 32 & 0.65 \\
\hline Kidney & 39 & 0.79 & Testis & 23 & 0.47 \\
\hline Larynx & 72 & 1.46 & Thymus & 10 & 0.20 \\
\hline Lip & 3 & 0.06 & Thyroid gland & 204 & 4.15 \\
\hline Liver and intrahepatic bile ducts & 183 & 3.72 & Tonsil & 18 & 0.37 \\
\hline Lymph nodes & 268 & 5.45 & Tongue & 55 & 1.12 \\
\hline Meninges & 74 & 1.51 & Trachea & 1 & 0.02 \\
\hline Mouth & 12 & 0.24 & Unknown primary sites & 42 & 0.85 \\
\hline Nasal cavity and middle ear & 57 & 1.16 & Ureter & 3 & 0.06 \\
\hline Nasopharynx & 269 & 5.47 & Urethra & 2 & 0.04 \\
\hline Oropharynx & 3 & 0.06 & Uterus & 5 & 0.10 \\
\hline $\begin{array}{l}\text { Other and ill-defined sites of head, } \\
\text { face, or neck }\end{array}$ & 24 & 0.49 & $\begin{array}{l}\text { Vagina } \\
\text { Vulva }\end{array}$ & $\begin{array}{l}11 \\
10\end{array}$ & $\begin{array}{l}0.22 \\
0.20\end{array}$ \\
\hline
\end{tabular}

Accurate and updated data are needed to relieve the burden of cancer. A proper registration and reporting system should be enacted to guide cancer treatment policy making. However, until 
today, there are no nationwide population-based cancer registry (PBCR). Consequently, incidence and prevalence of cancers cannot be properly assessed. Efforts to compile PBCR has been started at Cipto Mangunkusumo Hospital (Rumah Sakit dr. Cipto Mangunkusumo (RSCM) by establishing a hospital-based cancer registry (HBCR). The data collected at RSCM will be beneficial to complete PBCR in Jakarta and Indonesia. This study aims to report epidemiological and demographical profiles of cancer at RSCM in 2013. This study will help to decide a proper policy regarding cancer treatment and serve as a reference for the future HBCR research in Indonesia.

\section{Methods}

This retrospective descriptive study was conducted by collecting data from cancer registry system in RSCM in 2013 and the study was done in May-July 2016. The subjects of the study were all cancer patients who were diagnosed in 2013 and recorded in medical records from January $1^{\text {st }}$ to December $31^{\text {st }}, 2013$. Subjects were collected using total sampling technique.

Inclusion criteria are patients with cancer, who have been diagnosed by pathological anatomy criteria or another diagnostic procedure at RSCM and recorded at cancer registry. There were no exclusion criteria in this study. The variables studied were (1) The number of cancer cases at RSCM in 2013. (2) The most prevalent cancer cases. (3) Demographical data (age, gender, address, and job). (4) Cancer distribution based on tumor location (5) Staging distribution of top three most prevalent cancers. (6) Histopathological type distribution of top three most prevalent cancers. The data was analyzed descriptively: frequency and distribution of cancer based on age, gender, address, and histopathological type using Canreg5 and SPSS 20.

\section{Results \\ Patients Characteristics}

In January-December 2013 there were 59,954 outpatient visits (Table 1) and 6300 inpatient of cancer-related diagnoses (ICD-10 C, D, Z). There were 4915 cancer cases; women were 2963 $(60.26 \%)$ more prevalent than men 1952 (39.74\%).

This study found that age group of 45-54-yearold was the most common age for developing malignancy with 1294 cases (26.32\%) and the least common was < 25-year-old groups. Age distribution stratified by sex was presented in Table 2. Cancer in women were more prevalent among 44-54-year-old group with 889 cases $(30 \%)$ and the least prevalent were among the women under 24 . In contrast, the highest number of cancer in men were among 55-64 year-old with 422 cases (21.64\%), and the lowest were among men under 24 (Table 2).

Table 2. Age Distribution of Cancer Cases Stratified by Gender

\begin{tabular}{crrrrrr}
\hline \multirow{2}{*}{$\begin{array}{c}\text { Age Group } \\
\text { (years old) }\end{array}$} & \multicolumn{2}{c}{ Male } & \multicolumn{2}{c}{ Female } & \multicolumn{2}{c}{ Total } \\
\cline { 2 - 7 } & $\mathbf{n}$ & $\boldsymbol{~ \%}$ & $\mathbf{n}$ & $\%$ & $\mathbf{n}$ & $\%$ \\
\hline$<5$ & 123 & 6.3 & 94 & 3.17 & 217 & 4.42 \\
$5-14$ & 125 & 6.4 & 92 & 3.11 & 217 & 4.42 \\
$15-24$ & 120 & 6.15 & 104 & 3.51 & 224 & 4.56 \\
$25-34$ & 159 & 8.15 & 279 & 9.42 & 438 & 8.91 \\
$35-44$ & 281 & 14.39 & 692 & 23.35 & 973 & 19.80 \\
$45-54$ & 405 & 20.75 & 889 & 30.0 & 1294 & 26.33 \\
$55-64$ & 422 & 21.62 & 565 & 19.07 & 987 & 20.08 \\
$\geq 65$ & 317 & 16.24 & 248 & 8.37 & 565 & 11.50 \\
\hline
\end{tabular}

The most common jobs were employee (14.49\%) and homemaker (12.56\%). The rest of the jobs are farmer, military or police officer, laborer, medics, teacher, and entrepreneurs. Nevertheless, $12 \%$ of the subjects' jobs were unknown due to unreported data in the medical records. Based on patients' addresses, majority of the patients came from outside of Jakarta (51.94\%). On the other hand, patients from Jakarta were only $43.76 \%$. The rest of data had no addresses recorded (unknown).

\section{Cancer Distribution based on Tumor Location}

Based on the tumor location, top three cancers were breast cancer $(13.33 \%)$, cervical cancer $(12.55 \%)$, and hematopoietic and reticuloendothelial systems (8.97\%). Ten most prevalent cancers found at RSCM during 2013 were presented in Table 3. 
Table 3. Ten Most Prevalent Cancers at RSCM in 2013

\begin{tabular}{|c|c|c|c|c|c|c|c|c|}
\hline \multicolumn{3}{|c|}{ Both } & \multicolumn{3}{|c|}{ Male } & \multicolumn{3}{|c|}{ Female } \\
\hline Organs & $\mathbf{n}$ & $\%$ & Organs & $\mathbf{n}$ & $\%$ & Organs & $\mathbf{n}$ & $\%$ \\
\hline Breast & 655 & 13.33 & $\mathrm{HRS}^{*}$ & 249 & 12.76 & Breast & 645 & 21.77 \\
\hline Cervix uteri & 617 & 12.55 & Nasopharynx & 190 & 9.73 & Cervix uteri & 617 & 20.82 \\
\hline $\mathrm{HRS}^{*}$ & 441 & 8.97 & Lymph nodes & 170 & 8.71 & Ovary & 222 & 7.49 \\
\hline Nasopharynx & 269 & 5.47 & LIBD $^{* *}$ & 142 & 7.27 & $\mathrm{HRS}^{*}$ & 192 & 6.48 \\
\hline Lymph nodes & 268 & 5.45 & Prostate gland & 112 & 5.74 & Thyroid gland & 161 & 5.43 \\
\hline Ovary & 222 & 4.52 & Skin & 86 & 4.41 & Lymph nodes & 97 & 3.27 \\
\hline Thyroid gland & 204 & 4.15 & Bronchus and lung & 80 & 4.10 & Corpus uteri & 89 & 3.00 \\
\hline LIBD $^{* *}$ & 183 & 3.72 & Rectum & 77 & 3.94 & Rectum & 82 & 2.77 \\
\hline Rectum & 159 & 3.23 & Colon & 72 & 3.69 & Nasopharynx & 79 & 2.67 \\
\hline Skin & 155 & 3.15 & Larynx & 65 & 3.33 & Skin & 68 & 2.29 \\
\hline
\end{tabular}

${ }^{*}$ Hematopoietic and reticuloendothelial systems

**Liver and intrahepatic bile duct

\section{Cancer Distribution based on Diagnostic Procedure}

Based on the diagnostic procedure, most of the cancers were diagnosed by primary pathology anatomy evaluation (68.69\%), followed by clinical evaluation $(15.81 \%)$, and imaging procedures $(9.07 \%)$. Other category is microscope-verified cancer lesion (microscopic verification/MV) which consists of cytology $(1.49 \%)$, metastatic histology $(1.26 \%)$ and primary histology (68.69\%).

\section{Top Three Most Prevalent Cancer based on Age}

For every cancer which sits in the top three, analysis based on age was carried out to observe the distribution of the cancer (Figure 1). Breast cancer was dominant among 45-54 years old (217 cases), followed by $35-44$ years old (193 cases), and $55-64$ years old (123 cases). Similarly, cervical cancer was dominant among 45-54 years old (240 cases), followed by $35-44$ years old (155 cases) and 55-66 years old (143 cases). In contrast, hematopoietic and reticuloendothelial systems was prevalent among children on the age of 5 (100 cases) and 5-14 years old (103 cases), lastly on 35-44 years old (54 cases).

\section{Cancer Distribution in Women}

The prevalence of the cancers in women were breast cancer $(21.77 \%)$, cervical cancer $(20.82 \%)$, ovarian cancer $(7.49 \%)$, hematopoietic and reticuloendothelial systems cancer $(6.49 \%)$, thyroid gland cancer $(5.43 \%)$, lymphoma $(3.27 \%)$, uterine cancer $(3 \%)$, rectum cancer $(2.77 \%)$, nasopharyngeal cancer $(2.67 \%)$ and skin cancer $(2.99 \%)$.

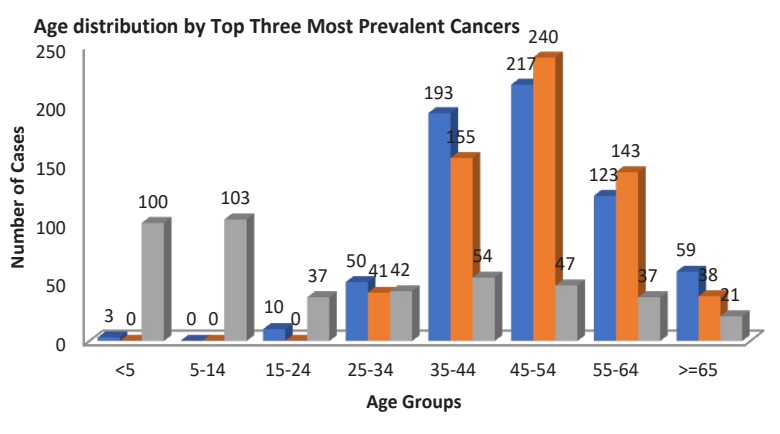

- breast $\square$ cervix $\square$ hematopoetic

Figure 1. Age Distribution Stratified by Top Three Most Prevalent Cancers at RSCM, 2013 ( $n=5554)$

\section{Cancer Distribution in Men}

The prevalence of the cancers in men were hematopoietic and reticuloendothelial Systems cancer $(12.76 \%)$, nasopharyngeal cancer $(9.73 \%)$, lymphoma $(8.71 \%)$, cancer $(7.27 \%)$, prostate cancer $(5.74 \%)$, skin cancer $(4.41 \%)$, bronchus and lung cancer $(4.1 \%)$, rectum cancer $(3.94 \%)$, and laryngeal cancer (3.33\%).

\section{Cancer Distribution based on Cancer Staging}

Among the most prevalent cancers, breast and cervical cancers were the only type of cancer which could be analyzed based on its staging due to the rest of cancers, such as bone marrow malignancy, were coded as "not applicable". Distribution of breast dan cervical cancer staging is presented on Table 4. 
Table 4. Breast and Cervical Cancer Staging Distribution

\begin{tabular}{lcccc}
\hline \multirow{2}{*}{ Stage } & \multicolumn{2}{c}{ Breast Cancer } & \multicolumn{2}{c}{ Cervical Cancer } \\
\cline { 2 - 5 } & $\mathbf{n}$ & $\%$ & $\mathbf{n}$ & $\%$ \\
\hline 1 & 7 & 1.07 & 5 & 0.81 \\
1A & 12 & 1.83 & 1 & 0.16 \\
1B & 3 & 0.46 & 52 & 8.43 \\
1C & - & - & - & - \\
2 & 11 & 1.68 & 7 & 1.13 \\
2A & 29 & 4.43 & 38 & 6.16 \\
2B & 26 & 3.97 & 123 & 19.94 \\
3 & 14 & 2.14 & 2 & 0.32 \\
3A & 26 & 3.97 & 10 & 1.62 \\
3B & 86 & 13.13 & 226 & 36.63 \\
$3 \mathrm{C}$ & 23 & 3.51 & 0 & 0.00 \\
4 & 125 & 19.08 & 9 & 1.46 \\
$4 \mathrm{~A}$ & 5 & 0.76 & 18 & 2.92 \\
$4 B$ & 4 & 0.61 & 21 & 3.40 \\
$4 \mathrm{C}$ & 1 & 0.15 & - & - \\
unknown & 283 & 43.21 & 105 & 17.02 \\
\hline
\end{tabular}

\section{Cancer Distribution based on Histopathological Findings}

Based on the histopathological findings (Table 5), infiltrating duct carcinoma was the most prevalent type of breast cancer $(75.57 \%)$, followed by carcinoma $(5.09 \%)$, lobular carcinoma $(4.87 \%)$, mucinous adenocarcinoma (3.54\%), and phyllodes malignant tumor $(2.88 \%)$.

Table 5. Breast and Cervical Cancer Distribution Based on Histopathology at RSCM in 2013

\begin{tabular}{|c|c|c|c|c|c|}
\hline Breast & $\mathbf{n}$ & $\%$ & Cervix & $\mathbf{n}$ & $\%$ \\
\hline Infiltrating duct carcinoma & 328 & 72.57 & $\begin{array}{l}\text { Squamous cell carcinoma, large cell, } \\
\text { nonkeratinizing, NOS }\end{array}$ & 271 & 48.31 \\
\hline Carcinoma, NOS & 23 & 5.09 & $\begin{array}{l}\text { Squamous cell carcinoma, keratinizing, } \\
\text { NOS }\end{array}$ & 87 & 15.51 \\
\hline Lobular carcinoma, NOS & 22 & 4.87 & Adenocarcinoma, NOS & 64 & 11.41 \\
\hline Mucinous adenocarcinoma & 16 & 3.54 & Adenosquamous carcinoma & 39 & 6.95 \\
\hline Phyllodes tumor. malignant & 13 & 2.88 & Squamous cell carcinoma, NOS & 36 & 6.42 \\
\hline Neoplasm, malignant & 11 & 2.43 & Carcinoma, NOS & 20 & 3.57 \\
\hline Adenocarcinoma, NOS & 7 & 1.55 & Neuroendocrine carcinoma, NOS & 5 & 0.89 \\
\hline $\begin{array}{l}\text { Infiltrating duct mixed with } \\
\text { other types of carcinoma }\end{array}$ & 5 & 1.11 & Endometrioid carcinoma, NOS & 5 & 0.89 \\
\hline Medullary carcinoma, NOS & 4 & 0.88 & Small cell carcinoma, NOS & 4 & 0.71 \\
\hline $\begin{array}{l}\text { Infiltrating duct and lobular } \\
\text { carcinoma }\end{array}$ & 4 & 0.88 & Mucinous Adenocarcinoma, NOS & 4 & 0.71 \\
\hline others & 19 & 4.20 & Others & 26 & 4.63 \\
\hline
\end{tabular}

Squamous cell carcinoma was the most prevalent type of histopathological finding among cervical cancer $(70.23 \%)$ which was further classified into nonkeratinized (48.31\%) and keratinized (15.51\%), succeeded by adenocarcinoma $(11.41 \%)$. There were also other minor types of cervical cancer, such as mucoepidermoid carcinoma $(0.18 \%)$ and signet ring cell carcinoma $(0.18 \%)$. In regards to hematopoetic and reticuloendothelial systems cancer, most cases were acute lymphoblastic leukemia $(30.39 \%)$, followed by chronic myeloid leukemia $(19.95 \%)$, and acute myeloid leukemia (12.02\%). 


\section{Discussion}

Throughout 2013, new cancer cases (4915) were diagnosed at RSCM, doubled the numbers from the data published by Sibuea et al. ${ }^{4}$ They reported only 2144 new cancer cases during the January 1997 - December 1998. In 15 years, cancer cases increased by 2.5 -fold.

The ratio between men and women is in accordance with the data published by Globocan ${ }^{5}$ in 2012, which stated that the number of cancer patients in Southeast Asia for five years was 1237 for men and 2041 for women. ${ }^{5}$ Compared with the data from $1997-1998,{ }^{4}$ the ratio was still consistent, albeit a slight difference. In 2013 HBCR ratio for women and men was 3:2, whereas in 1997 the ratio was 17:10 for women and men. Nevertheless, this ratio is not consistent with the global trend of cancer.

Age distribution showed that the most prevalent age group of cancer patients at RSCM is 45-54 year-old, older than data from 1997-1998 which was $35-44$ year-old. ${ }^{4}$ The transition is similar with epidemiological trend worldwide. ${ }^{6}$ The worldwide cancer trend, which correlates to western lifestyle, such as breast, prostate, endometrial, and other cancers, would increase as the age increases. ${ }^{6,7}$

If the age distribution is further stratified by sex, peak age of cancer in women and men would be different. In women, peak age of cancer appeared in 45-54 years old, whereas it is older in men, which was in 55-64 years old. PBCR data from 1997-1998 revealed the same results, peak age of cancer incidence in men was also 55-64 years old.

Homemaker is the most common job reported among cancer patients at RSCM, followed by employee, and other jobs which are not classified in the job list. On the other hand, there are also a high number of unreported jobs in the medical records. Homemaker and employee are not high-risk jobs for cancer. Furthermore, the Srikandi questionnaire did not specifically make a category for certain jobs that pose a high risk to cancer as stated in several studies. This is an important point to consider for a better cancer patients' registration in the future.

The majority of the cancer patients came from outside Jakarta, compared to Jakarta-based patients. This number showed that patients all over the country were referred into RSCM. Therefore, improvement on referral system and health care facilities on primary or secondary level should be made so cancer patients can be treated evenly by health care facilities on each province or district. However, there are still 500 patients $(9 \%)$ whose addresses were missing. This unfortunate circumstance has caused a significant problem in supporting transition from HBCR to PBCR.

The most prevalent cancers based on tumor location were breast cancer, cervical cancer and hematopoietic and reticuloendothelial systems cancer. Breast cancer was in accordance with worldwide data. Besides that, Singapore (Malay ethnic group), Malaysia (Malay ethic group), and Thailand, whose ethnic profile is similar to Indonesia, also found breast cancer as the most prevalent cancer.

In terms of age distribution of breast cancer, cervical cancer, and hematopoietic and reticuloendothelial systems cancer. Group 45-54-year-old was the most susceptible age group of breast and cervical cancer, which is consistent with the analysis of Leong, et al. ${ }^{8}$ The study showed that there is a difference among peak age of patients with breast cancer in Asia and Western countries. In Asia, peak age of incidence was 40-50 years old, while it was 60-70 years old in Western countries. Leong et $\mathrm{al}^{8}$ also stated that the incidence of breast cancer was increasing in Asia. This is consistent with the findings of HBCR from RSCM which found that breast cancer was on the number three in 1997-1998, but it was number one in 2013.

Ban et $\mathrm{al}^{7}$ stated that breast cancer incidence worldwide is increasing as the age gets older. However, the incidence is falling on the 75 years older in patients with positive estrogen receptor $(E R+)$. In contrast, patients with negative estrogen receptor (ER-) incidence is increasing as the age approach 50 , followed by a constant number of patients. Patients who had breast cancer after menopause commonly had negative estrogen receptor.

The most susceptible age group to cervical cancer was also 45-54-year-old, consistent with the data in Taiwan. However, increase in cervical cancer frequency compared to data in 1997-1998 must be analyzed further. Although the absolute number increased, the percentage of cervical cancer decreased, from $22.38 \%$ on $1997-1998$ into $12.21 \%$ in 2013 . This trend is consistent with falling cervical cancer trend after the introduction of cytological screening and human papilloma virus (HPV) vaccination. Data from Malaysia and Thailand also showed that highest HPV infection are on 20-24 and 50-54 year old groups. ${ }^{9}$

In this HBCR, in contrast with the two previous cancers, hematopoietic and reticuloendothelial systems cancer peak age incidence was under 
15 years old $(46,03 \%)$. Leukemia was the most common children malignancy, with $30 \%$ of cancer under 15 years old being leukemia. HBCR from RSCM in 1997-1998 showed a markedly significant difference from the 2013 HBCR. Ten of the most prevalent cancers in women were breast cancer, cervical cancer, nasopharyngeal cancer, thyroid cancer, colorectal cancer, skin cancer, bone marrow cancer, ovarian cancer, and lymphoma. In 2013, there was a huge increase in breast, ovarian, and bone marrow cancer. Uterine and brain malignancies, which were not listed in 1997-1998 top ten, emerged as the newcomers in 2013.

In men, ten of the most prevalent cancers in 1997-1998 were nasopharyngeal cancer, bone marrow cancer, liver cancer, lymphoma, colorectal cancer, skin cancer, eyes cancer, bladder cancer, prostate cancer, and kidney cancer. In 2013, bone marrow, lung, brain, and laryngeal malignancies, which were the least frequent types of cancer and were strongly associated with cigarette exposure, markedly increased. Compared to neighboring countries, the most prevalent cancers among men in Thailand were lung, liver, and colorectal cancers. ${ }^{10}$ In Singapore, lung, prostate, and colorectal cancers were prevalent. In Malaysia, lung, prostate, and colorectal cancers were prevalent. Interestingly, prostate cancer which always showed a high incidence worldwide only sits at six out of ten most prevalent malignancies.

Breast cancer patients mostly came in stage IV, followed by IIIB, IIA and IIB, and IIIA. The rest of the patients came with stage II or below. For 283 patients, staging data were unreported and further appeared on medical record as TxNxMx. Nevertheless, it can be concluded that breast cancer patients in Indonesia came after advanced stage of the malignancies. In America, Caucasians are commonly diagnosed in stage I-II, whereas African Americans in stage IIB or above. ${ }^{11}$ One of the important factors that plays a major role is socio-economic factor, which caused patients to seek medical treatment after the conditions have become severe. Similar situation was observed in cervical cancer patients. Patients mostly came in locally advanced stage of cervical cancer with stage IIIB as the most prevalent stage.

Based on histopathological findings, infiltrating duct carcinoma was the most prevalent type of breast cancer followed by carcinoma, lobular carcinoma, mucinous adenocarcinoma and phyllodes malignant tumor. Tjahjadi et al ${ }^{11}$ reported that $80 \%$ of the breast cancer cases were invasive ductal carcinoma. Therefore, actual incidence of invasive ductal carcinoma in HBCR from RSCM was predicted to be higher in number. This is because there are numerous clinical data that were yet to be confirmed by histopathological examination and coded as 8000 (malignant neoplasm) and 8010 (carcinoma, NOS).

Most of the leukemia cases were acute lymphoblastic leukemia, followed with chronic myeloid leukemia and acute myeloid leukemia. Study by Belson et $\mathrm{al}^{12}$ showed the most prevalent ( $75 \%$ cases) of childhood cancer is acute lymphoblastic leukemia, followed by $\mathrm{CML}$ and AML, and others type. This is consistent with HBCR data from RSCM in 2013. Nevertheless, there are several recommendations in improving the HBCR. We recommend a better medical record registration based on national ID card number to prevent double recordings. Integrated medical record system which can be easily accessed by researchers is also urgently needed. Furthermore, every medical record must be filled completely. Improvement in Srikandi questionnaire can be made in job section, with special concerns regarding certain jobs which are susceptible to carcinogen exposure. Moreover, since most patients came with advanced or locally advanced stage, we also recommend a proper resource allocation regarding cancer treatment, especially radiotherapy and chemotherapy. Lastly, we recommend a continuous collection of $\mathrm{HBCR}$, thus cancer trend can be detected over the year. HBCR is a good start to register cancer data; nevertheless, accurate depiction of cancer situation can only be made by population-based cancer registry.

\section{Conclusion}

There were 4915 new cancer cases in 2013 and most of the patients were 45-54 years old for both sexes, 45-54 years old in women, and 55-64 years old in men. The ratio of women and men was 3:2. In 2013, RSCM served more cancer patients who came from outside Jakarta than patients from Jakarta. The most common job among the patients was homemaker. Breast and cervical cancer, hematopoietic and reticuloendothelial systems cancer were the most common types. In women, breast, cervical, and hematopoietic and reticuloendothelial systems cancers were the most prevalent. On the other hand, hematopoietic and reticuloendothelial systems cancer, nasopharyngeal cancer, and lymphoma were the most common cancers among men. The majority of breast and 
cervical cancer patients came in advanced stage and locally advanced stage. The top three cancer types were infiltrating duct carcinoma of breast cancer, nonkeratinized squamous cell carcinoma of cervical cancer, and acute lymphoblastic leukemia.

\section{References}

1. Torre LA, Bray F, Siegel RL, Ferlay J, Lortet-tieulent J, Jemal A. Global cancer statistics, 2012. CA a cancer J Clin. 2015;65:87-108. Available from http:// onlinelibrary.wiley.com/doi/10.3322/caac.21262/ abstract/.

2. Ministry of Health of Republic of Indonesia. Riset kesehatan dasar 2013 [Basic health research 2013]. Jakarta: Kementerian Kesehatan Republik Indonesia; 2013. Indonesian.

3. Badan Penyelenggara Jaminan Sosial Kesehatan. Pelayanan PET scan, radioterapi eksterna dan brakiterapi dalam era JKN (PET scan, external body radiation therapy, and brachytherapy services in the era of National Health Insurance). Jakarta: Badan Penyelenggara Jaminan Sosial Kesehatan; 2016. Indonesian.

4. Sibuea W, Mangunkusumo R, Akbar N, Widjanarko A, Gatot D. Hospital based cancer registry at Cipto Mangunkusumo hospital Jakarta. Med J Ind. 2000;9:181-203.
5. Globocan. Fact sheets by population. Int Agency Res [Internet]. [cited 2020 Jul 31]; 2014. Available from http://globocan.iarc.fr/Default.aspx/.

6. Bray F, Ren J-S, Masuyer E, Ferlay J. Global estimates of cancer prevalence for 27 sites in the adult population in 2008. Int J Cancer. 2013;132:1133-45.

7. Ban KA. Epidemiology of breast cancer: breast cancer epidemiology risk factors. J Surg Oncol Clin NA. 2016;23:409-22.

8. Leong SPL, Liu ZST, Derossis A, Cody H, Foulkes WD. Is breast cancer the same disease in Asian and western countries? World J Surg. 2010;2308-24.

9. Kuie S, Ngan HYS, Chu T, Cheung ANY, Hseon E. Epidemiology of human papillomavirus infection and cervical cancer and future perspectives in Hong Kong, Singapore and Taiwan. Vaccine. 2008;26 Suppl 12:M60-70.

10. Parkin DM, Pisani P, Ferlay J. Global cancer statistics. CA Cancer J Clin. 1999;49:33-64.

11. Tjahjadi G, Prihartonol J, Ramli M. Pathological aspects of breast cancer in Indonesian females, emphasizing on the modified WHO classification. Med J Ind. 1991;467.

12. Belson M, Kingsley B, Holmes A. Risk factors for acute leukemia in children: a review. Enviromental Health Perspect. 2007;138:138-45. 